stans, Tectona grandis, Terminalia bellirica, $T$. crenulata, Trema orientalis, T. politoria, Wrightia tinctoria, W. tomentosa, Zizyphus mauritiana, Z. oenoplia, and Z. xylopyra (Chavan \& Oza, 1966).

Future generations of Indians, if we endeavour to implement the exemplary IPCL case (under the leadership of its Chairman and Managing Director, Dr Subrato Ganguly) elsewhere in the country, should be fortunate enough to witness a 'living museum of trees typical to our country'. The present Author has long cherished a strong conviction that it is only such actions which will serve the cause of Indian forestry and establish long-term environmental conditions that are really conducive to human welfare.

The choice of tree taxa should ensure that something is flowering or fruiting practically around the year, while the large-leafed species should contribute to the abatement of pollution. Moreover the ultimate selection of trees ought also to take care of the ornamental, aesthetic, and landscape, aspects. Around the residential complex of IPCL, a move is afoot to have the trees selected and planted to form avenues of particular species, so that it ought to be possible for us to name and recognize areas or sectors that are based on the names of the plants which constitute our rich heritage.
REFERENCES

Chavan, A.R. \& Oza, G.M. (1966). The Flora of Pavagadh, Gujarat State, India. Bot. Mem. M.S. Univ. Baroda, No. 1, viii +296 pp., illustr.

OzA, G.M. (1975). The dangers of dumping wastes into sea and river waters of India. Environmental Conservation, 2(1), pp. $59-60$, fig.

OzA, G.M. (1981). Save trees, save India. Environmental Conservation, 8(3), p. 248.

OzA, G.M. (1982). Save trees, save our Biosphere! Environmental Conservation, 9(3), pp. 255-6, fig.

Oza, G.M. (1983). On the eve of 'Vanmahostava'. Indian For., 109, pp. 113-20, fig.

OzA, G.M. (1985). 'Guardians of the Trees'. Environmental Conservation, $12(2)$, pp. 182-3, fig.

G.M. OzA, FLS

Reader in Botany

General Secretary of INSONA

Faculty of Science

Maharaja Sayajirao University of Baroda

Baroda 390002

India.

\title{
The International Centre for Conservation Education
}

With the main object of promoting improved understanding of conservation and the environment as widely as possible, the International Centre for Conservation Education (ICCE) was officially opened in 1984 on June 5th, World Environment Day. It is an independent centre with charitable status which started in 1975 as World Wildlife Fund (WWF) Project 1180: 'a special project for the promotion of conservation education in developing countries'. ICCE's principal objectives are to expand and consolidate the work of the International Union for Conservation of Nature and Natural Resources (IUCN)-WWF International Education Project and to act as a technical support-unit and global focus for international conservation education activities at a very practical level. ICCE is now the operational base for three international conservation education programmes: the IUCN-WWF International Education Project, the Elsa Wild Animal Appeal, and the ICCE Wildlife Brass-rubbing Scheme.

Over the past ten years, starting with the above-mentioned WWF Project, we have been directly involved with educational projects in more than fifty countries. The Centre's staff have practical experience and knowledge of conservation problems in developing countries through work with United Nations and other international conservation and development agencies. This experience has emphasized the need for simple, effective means of communicating the importance of environmental conservation at all levels-ranging from rural populations and schoolchildren, to government officials and decision-makers.

\section{Concentration on Audio-visual Programmes}

In the early days of our operation, a good deal of research was carried out on the most appropriate educational materials for use in a wide variety of situations, and on the selection and field-testing of appropriate equipment. It was decided to concentrate on audio-visual (AV) programmes, mainly for reasons of cost and flexibility. For such purposes the same original material can be used to prepare filmstrips or slide-sets (or both), while programmes can be regularly updated as new information becomes available, and readily adapted to suit different situations and/or audiences etc. Thus it is relatively easy to prepare one commentary or set of notes for ten-year-olds and another for adults; or one commentary for scientists and another for rural villagers. Other favourable factors are the low cost when compared with other visual media such as film or video, the high impact in a well-prepared situation, and the rapid reproduction- and distribution-times.

To date more than $85 \mathrm{AV}$ programmes have been produced and are in daily use world-wide to support local and national conservation activities as well as global campaigns. Most of the AV programmes have something to interest teachers and environmental groups in both developed and Third World countries - many are concerned with topics of general ecological interest such as habitat degradation, pollution, population, acid rain, renewable energy, and resource management.

\section{Rural Communities Important}

If these materials are to have the desired maximum effect, there is a need to reach out beyond the main centres of population and to provide varied and comprehensive public awareness programmes to rural communities. In 1976, two prototype Mobile Education Units were sent to Gambia and Senegal in West Africa where for years they toured schools, colleges, and villages, giving displays, talks, and $\mathrm{AV}$ presentations, on conservation subjects of local and international interest. In 1979 alone, some 25,000 Gambians became more aware of such important conservation issues as deforestation, desertification, and their local animals and plants. The response to the mobile education programme was so enthusiastic that the idea caught on in several other countries, and similar units have been supplied to the Wildlife Club movements in Cameroon and Uganda, the Chongololo Clubs of Zambia, the Wildlife Departments in Sri Lanka, Ethiopia, and Madagascar, and the Mountain Gorilla Project in Rwanda-funds being provided by a variety of conservation organizations.

\section{Mobile Units Specially Equipped}

To date, most mobile units have been based on the wellproven Renault Fourgon van which is extensively modi- 
fied and can be equipped with a portable generator, $16 \mathrm{~mm}$ film-projector, slide-tape unit, public address system, and display screens-all carried in foam-lined rigidized aluminium cases and compartments for safe travel on rough roads. Diesel-powered Land Rovers have also been equipped for areas where more difficult terrain is likely to be encountered.

Besides equipping mobile education units, the Centre provides comprehensive back-up support to information centres and field conservationists working in remote areas. Most of the equipment offered has been selected as the most appropriate for educational work and then 'field tested' to prove its value and reliability in operation. Photographic and printing services are also available, and spare parts can be ordered and despatched. ICCE's staff also visit developing countries to advise both government departments and non-government organizations on the establishment and development of national conservation education programmes.

\section{Training Courses and Newsletter}

Over the years, these activities have encouraged the establishment of similar environmental resource-centres by developing countries themselves. As part of this policy, the Centre initiated an international training course for nationals of Third World countries working in environmental education. Thanks to a generous donation by the Elsa Wild Animal Appeal and support from WWF International, it was possible to establish and equip the Joy Adamson Memorial Training Room at ICCE. This part of the Centre incorporates a small library and audio-visual projection facilities as well as providing the main working area for trainees. Courses are extremely practical, begin- ning where most theoretical teaching ends. They allow trainees to develop a variety of 'real' educational resources to assist them in their work. To date, four courses have been run and fifteen trainees, mostly from African countries, have produced a wide variety of educational aids relevant to their needs-including audio-visual programmes, posters, booklets, leaflets, certificates, and also materials such as calendars and lapel badges to help with fund-raising activities.

ICCE is also involved in several other activities which are not always easy to categorize: for example, to help promote greater cooperation between conservation organizations and environmental educators working in Africa, ICCE publishes the 'Africa Link' newsletter with funding from the Elsa Wild Animal Appeal. 'Africa Link' provides information, ideas, and practical advice, on all matters relating to conservation education in Africa-training, equipment, materials, funding agencies, and so on.

Success or failure for many conservation projects will depend increasingly on highly-motivated and well-trained local personnel who understand not only the conservation problems and dilemmas of their own country but also the cultural situation in which they occur. They will need appropriate resources to carry out the work-to inform, influence, and guide. They will need educational materials, new skills in communication, and continuing practical support. This is the challenge to which ICCE is responding.

PHILIP STEELE, Deputy Director
International Centre for Conservation Education
Greenfield House
Guiting Power
Cheltenham
Gloucestershire GL54 5TZ, England, UK.
International Centre for Conservation Education Greenfleld House

Cheltenham Gloucestershire GL54 5TZ, England, UK.

\section{Regulated Rivers}

Since the earliest 'hydraulic' civilizations, Man has sought to understand and to control rivers in order to optimize the economic benefits from their water and adjacent floodplain lands. Early civilizations along the Indus, Nile, Hwang Ho, and Tigris-Euphrates, flourished over long periods of history by managing their land and water resources in a way that harmonized the pursuit of economic objectives with the integrity of their environment. In contrast, the recent history of river management has been dominated by technological 'achievements': large multipurpose dams, long-distance water transfers, and widespread canalization. Moreover, technology has advanced more quickly than has our knowledge of the environmental consequences!

Virtually every major river in the world is now regulated in some way. The impacts include plant and animal species extinctions, loss of special habitats, destruction of traditional fisheries, and desertification or salinization of oncefertile floodplains. Many impacts have resulted directly from river regulation, but others are caused by secondary effects associated not least with increased discharges of agricultural, domestic, and industrial, effluents.

Today, integrated land and water management giving due regard to the maintenance of ecological balance is seen as a fundamental part of sustainable development policies. Furthermore, it is recognized that, utilizing appropriate management strategies, river regulation can make a positive contribution to environmental conservation. In order to realize the benefits for Nature and natural resources, and to minimize foreseeable impacts from future river regulation schemes, river management must utilize knowledge from critical appraisals of the past and present environmental problems of river 'developments', and must adopt an anticipatory approach to those problems. One additional need is to develop improved approaches and techniques for the restoration of damaged ecosystems.

To provide a focus for research on the environmental effects of river regulation, and to advance our knowledge of management alternatives, a new journal is being established. Regulated Rivers is an international journal dedicated to the promotion of interdisciplinary research and testing that is concerned directly or indirectly with river management. The journal is devoted to the rapid publication of scientific and technical papers on biological, ecological, engineering, and geographical, aspects relating to both the developed and 'developing' worlds. Research focusing on reservoirs, drainage-basin development, wetlands, estuaries, and the near-shore coastal zone, etc., may also be included if set in the context of the regulated river system. Topics will include, for example, fishway design, reservoir release strategies, water-quality control, channel erosion and sedimentation, changes of flora and fauna, problems of health and disease, and environmental modelling.

Supported by a truly international and multidisciplinary Editorial Board, Regulated Rivers will be published quarterly, commencing Autumn 1986, by John Wiley \& Sons, Chichester, England, UK. The subscription price is $£ 65.00$ or $\$ 110.00$.

Geoffrey E. Petts, Editor-in-Chief Department of Geography University of Technology Loughborough Leicestershire LE11 $3 T U$ England, UK. 